Received: 15 March 2019, Revised: 22 March 2019

Accepted: 16 April 2019, Published: 28 April 2019

Available online at: http://e-journal.unair.ac.id/index.php/IMHSJ

\title{
HUBUNGAN USIA DAN TINGKAT STRES DENGAN KEJADIAN INFERTILITAS DI POLI OBGYN RSUD Dr. SOETOMO SURABAYA
}

\section{RELATIONSHIP BETWEEN AGE AND STRESS LEVELS WITH INFERTILITY ACCIDENT IN POLI OBGYN RSUD dr. SOETOMO SURABAYA}

\author{
Dessy A. Ningsi ${ }^{1}$, Zakiyatul Faizah², Jimmy Yanuar Annas ${ }^{2}$
}

\author{
1. Program Studi Pendidikan Bidan, Fakultas Kedokteran, Universitas \\ Airlangga Surabaya \\ 2. Fakultas Kedokteran, Universitas Airlangga \\ Alamat korespondensi: \\ Jl. Tombolotutu no. 10, Palu, 94116 Indonesia \\ Email : alexya.091291@gmail.com
}

\begin{abstract}
Abstrak
Latar Belakang : Infertilitas merupakan problem yang dihadapi oleh pasangan suami istri yang telah menikah selama minimal satu tahun, melakukan hubungan seksual teratur tanpa menggunakan kontrasepsi tetapi belum berhasil memperoleh kehamilan. usia dan tingkat stres merupakan faktor yang berhubungan erat dengan tingkat kesuburan seorang wanita. Penelitian ini bertujuan untuk mengetahui hubungan antara usia dan tingkat stres dengan kejadian infertilitas. Metode : Penelitian ini adalah penelitian analitik observasional dengan desain hospital based case control di Poli Obgyn RSUD dr. Soetomo Surabaya yang dilakukan sejak bulan maret sampai bulai april 2019. Sampel yang digunakan dalam penelitian ini terdari dari 42 orang wanita infertil dan 42 orang wanita fertil yang diambil dengan metode Purposive Sampling. Data dianalisa menggunakan analisis bivariat menggunakan uji Chi Square dan uji Spearman. Hasil : Hasil penelitian menunjukkan pada kelompok kasus $76,2 \%$ responden berada pada kategori usia kurang dari 35 tahun dan pada kelompok kontrol sebanyak $81 \%$ pada kategori yang sama. Tingkat stress pada kelompok kasus dan kontrol masing - masing sebanyak $83,3 \%$ berada pada kategori normal. Hasil uji chi square antara usia dan kejadian infertilitas didapatkan $p$ value $=0,595$ ( $p$ value $>0,05)$. Hasil uji Spearman antara tingkat stress dengan kejadian infertilitas didapatkan $p$ value $=0,906$ ( $p$ value $>0,05)$. Kesimpulan: Hasil uji statistik menunjukkan tidak terdapat hubungan yang bermakna antara usia dan tingkat stress dengan kejadian infertilitas.
\end{abstract}

Kata kunci : infertilitas, usia, tingkat stres, hubungan

\begin{abstract}
Background: Infertility is a problem faced by married couples who have been married for at least one year, have regular sexual intercourse without using contraception but have not succeeded in obtaining a pregnancy. Age and stress level are factors that are closely related to a woman's fertility rate. This study aims to identify the relationship between age and stress levels with the incidence of infertility. Method: This study was an observational analytic study with a hospital based case control design at Poli Obgyn RSUD dr. Soetomo Surabaya was carried out from March until April 2019. The samples used in this study were from 42 infertile women and 42 fertile women taken using the Purposive Sampling method. Data were analyzed by bivariate analysis with Chi Square test and Spearman test. Result: The results of the study showed that in the case group $76.2 \%$ of respondents were in the age group of under 35 years and the control group as much as $81 \%$ in the same category. Stress levels in the case and control groups were $83.3 \%$ in the normal category respectively. The
\end{abstract}


results of the chi square test between age and the incidence of infertility obtained $p$ value $=0.595$ ( $p$ value $>0.05)$. The Spearman test results between stress levels and infertility events obtained $p$ value $=0.906$ ( $p$ value $>0.05)$. Conclusion: The results of the statistical test showed no significant relationship between age and stress level with the incidence of infertility.

Keywords: infertility, age, stress level, relationship

\section{PENDAHULUAN}

Infertilitas merupakan problem yang dihadapi oleh pasangan suami istri yang telah menikah selama minimal satu tahun, melakukan hubungan seksual teratur tanpa menggunakan kontrasepsi tetapi belum berhasil memperoleh kehamilan (Hestiantoro,2011). Infertilitas juga dapat didefinisikan sebagai ketidakmampuan untuk mempertahankan kehamilan sampai melahirkan bayi yang dapat bertahan hidup (Eniola, Adetola and Abayomi, 2012). Di Indonesia, menurut Badan Pusat Satastistik (BPS) pada tahun 2011 tercatat dari $\pm 39,8$ juta wanita usai subur terdapat $10-15 \%$ yang dinyatakan infertil dan angkanya terus meningkat setiap tahunnya (Sa'adah, 2016). Pada tahun 2013 jumlah pasangan infertil adalah $15-25 \%$ dari seluruh pasangan yang ada (Indarwati et al, 2017).

Infertilitas dapat dipengaruhi oleh berbagai faktor seperti lama infertilitas, usia perempuan, gaya hidup meliputi kebiasaan merokok, konsumsi alcohol, obesitas dan stress, serta faktor psikoemosional dan riwayat bedah pelvis atau infeksi rongga panggul. (Fauziyah, 2012). Pada wanita, puncak fertilitas terjadi pada pada rentang usia 18-25 tahun dan mulai menurun setelah usia 27 tahun dan akan menurun pesat setelah wanita berusia lebih dari 35 tahun. Hal ini berkaitan dengan kecukupan cadangan sel telur di ovarium (Eniola, Adetola and Abayomi, 2012). . Semakin tua usia wanita maka simpanan sel telur akan semakin menipis dengan kualitas yang semakin menurun pula disertai dengan mulai terjadinya ketidakseimbangan hormonal sehingga menyulitkan wanita untuk hamil (Djuwantono et al, 2008). Stres merupakan bagian dari yang tidak terpisahkan dari setiap individu baik itu stres fisik, sosial maupun psikologis. Tingkat stres secara signifikan memiliki pengaruh yang besar bagi fertilitas pria maupun wanita. Pada wanita, stres akan memicu tubuh untuk menghasilkan kortisol yang dapat mengganggu produksi FSH, maturasi folikel dan mengurangi jumlah sel telur yang matang serta dapat mempengaruhi kualitas dari sel telur tersebut (Sharma et al. 2013 ; Setiyono et al, 2015). 
Tujuan dari penelitian ini adalah untuk mengetahui hubungan antara usia dan tingkat stres dengan kejadian infertilitas di poli obgyn RSUD dr. Soetomo Surabaya. Hipotesis penelitian "Ada hubungan antara usia dan tingkat stres dengan kejadian kejadian infertilitas di poli obgyn RSUD dr. Soetomo Surabaya”.

\section{METODE}

Penelitian ini dilakukan di poli infertilitas dan poli hamil yang merupakan bagian dari poli obgyn RSUD dr. Soetomo Surabaya. Desain penelitian yang digunakan dalam penelitian ini adalah hospital based case contol dengan pendekatan retrospective. Populasi yang digunakan dalam penelitian ini adalah pasangan usia subur yang datang dan mendapatkan terapi di poli infertilitas dan poli hamil. Kelompok kasus adalah kelompok pasangan usia subur yang didiagnosa dan mendapat terapi di poli infertilitas. Kelompok kontrol adalah pasangan usia subur tanpa riwayat infertilitas yang memeriksakan diri di poli hamil RSUD dr. Soetomo Surabaya. Teknik pengambilan sampel yang digunakan adalah purposive sampling berdasarkan kriteria inklusi yaitu rekam medis lengkap dan jelas, sampel didiagnosis mengalami infertilitas untuk kelompok kasus, sampel telah memiliki anak atau sedang hamil dan tidak memiliki riwayat infertil sebelumnya untuk kelompok kontrol. Sampel yang diambil sebanyak 42 orang untuk masing - masing kelompok kasus dan kontrol.

Variabel penelitian terdiri atas variabel dependen yaitu infertilitas dan variabel independen yang terdiri dari usia dan tingkat stres. Definisi operasional meliputi : 
Tabel 1 definisi operasional variabel penelitian

\begin{tabular}{|c|c|c|c|c|c|}
\hline $\begin{array}{c}\text { Variabel } \\
\text { Penelitian } \\
\end{array}$ & Definisi Operasional & Alat Ukur & $\begin{array}{l}\text { Cara } \\
\text { Ukur } \\
\end{array}$ & $\begin{array}{l}\text { Skala } \\
\text { Ukur }\end{array}$ & Hasil Ukur \\
\hline Infertilitas & $\begin{array}{l}\text { Ketidakmampuan untuk } \\
\text { hamil setelah melakukan } \\
\text { hubungan seksual secara } \\
\text { teratur dan tanpa } \\
\text { perlindungan kontrasepsi } \\
\text { selama lebih dari } 1 \text { tahun } \\
\text { pada wanita yang } \\
\text { usianya } \leq 35 \text { tahun dan } \\
\text { lebih dari } 6 \text { bulan pada } \\
\text { wanita yang usianya }>35 \\
\text { tahun. }\end{array}$ & $\begin{array}{l}\text { Lembar } \\
\text { pengumpu } \\
\text { l data }\end{array}$ & $\begin{array}{l}\text { Rekam } \\
\text { medis }\end{array}$ & Nominal & $\begin{array}{ll}\text { 1. } & \text { Tidak infertil } \\
\text { (Bila } \\
\text { didiagnosa } \\
\text { sebagai } \\
\text { pasangan yang } \\
\text { tidak infertil) } \\
\text { 2. } & \text { Infertil (Bila } \\
\text { didiagnosa } \\
\text { sebagai } \\
\text { pasangan } \\
\text { infertil) }\end{array}$ \\
\hline Usia & $\begin{array}{l}\text { Jumlah usia ibu sejak } \\
\text { dilahirkan sampai } \\
\text { dengan dilakukan } \\
\text { penelitian yang ditulis } \\
\text { responden dalam lembar } \\
\text { kuesioner. }\end{array}$ & Kuesioner & Kuesioner & Nominal & $\begin{array}{l}\text { 1. } \leq 35 \text { tahun } \\
\text { 2. }>35 \text { tahun }\end{array}$ \\
\hline Tingkat Stres & $\begin{array}{l}\text { Respon ibu terhadap } \\
\text { berbagai tekanan atau } \\
\text { tuntutan eksternal dan } \\
\text { menghasilkan berbagai } \\
\text { gangguan meliputi fisik, } \\
\text { emosional dan prilaku. }\end{array}$ & Kuesioner & $\begin{array}{l}\text { Kuesioner } \\
\text { DASS } 42\end{array}$ & Ordinal & $\begin{array}{l}\text { 1. Normal (bila } \\
\text { skor jumlah } \\
\text { kategori stres, } \\
\text { kecemasan dan } \\
\text { depresi berada } \\
\text { pada rentang } 0 \\
\text { - 30) } \\
\text { 2. Stres ringan } \\
\text { (bila skor } \\
\text { jumlah kategori } \\
\text { stres, } \\
\text { kecemasan dan } \\
\text { depresi berada } \\
\text { pada rentang } 31 \\
\text { - 40) } \\
\text { 3. Stres berat (bila } \\
\text { skor jumlah } \\
\text { kategori stres, } \\
\text { kecemasan dan } \\
\text { depresi } \geq 41 \text { ) }\end{array}$ \\
\hline
\end{tabular}

Pengumpulan data dilakukan pada bulan maret - april 2019. Pengumpulan data dilakukan dengan menggunakan data primer dan sekunder. Instrumen penelitian untuk variabel usia menggunakan kuesioner yang telah di uji validitas, variabel stres menggunakan kuesioner depression anxiety stress scale 42 (DASS 42) dan diagnosa infertilitas menggunakan data yang tertera dalam rekam medis. Pengolahan data dilakukan dengan editing, coding, entry, cleaning dan tabulating data. Analisis data dalam penelitian ini menggunakan uji Chi square untuk variabel usia dan uji Spearman untuk variabel tingkat stres dengan tingkat 
kepercayaan 95\% yang diolah menggunakan program komputer SPSS. Uji ini dilakukan untuk melihat apakah ada hubungan antara variabel dependen dan independen dengan nilai signifikansi $\alpha<0,05$.

\section{HASIL DAN PEMBAHASAN}

\section{Hubungan usia dengan kejadian infertilitas}

Tabel 2 hubungan usia dengan kejadian infertilitas

\begin{tabular}{|c|c|c|c|c|c|c|c|c|}
\hline \multirow{3}{*}{$\begin{array}{l}\mathbf{N} \\
\mathbf{0}\end{array}$} & \multirow{3}{*}{ Variabel } & \multicolumn{4}{|c|}{ Infertilitas } & \multirow{2}{*}{\multicolumn{2}{|c|}{ Total }} & \multirow{3}{*}{ p value } \\
\hline & & \multicolumn{2}{|c|}{ Kasus } & \multicolumn{2}{|c|}{ Kontrol } & & & \\
\hline & & $\mathrm{F}$ & $\%$ & $\mathrm{~F}$ & $\%$ & $\mathrm{~F}$ & $\%$ & \\
\hline \multicolumn{9}{|c|}{ 1. Usia ibu } \\
\hline & $\leq 35$ tahun & 32 & 76,2 & 34 & 81,0 & 66 & 78,6 & \multirow[t]{2}{*}{0,595} \\
\hline & $>35$ tahun & 10 & 23,8 & 8 & 19,0 & 18 & 21,4 & \\
\hline
\end{tabular}

Tabel 2 menunjukkan bahwa mayoritas responden pada kelompok kasus dan kelompok kontrol termasuk kedalam kategori usia $\leq 35$ tahun yaitu sebanyak $76,2 \%$ dan $81 \%$. Hasil uji chi square menunjukkan nilai $p$ value $>0,05$ ( $p$ value $=$ $0,595)$ yang artinya tidak ada hubungan yang signifikan antara usia ibu dengan kejadian infertilitas

\section{Hubungan tingkat stres dengan kejadian infertilitas}

Tabel 3 hubungan tingkat stres dengan kejadian infertilitas

\begin{tabular}{|c|c|c|c|c|c|c|c|c|}
\hline \multirow{3}{*}{$\begin{array}{l}\mathbf{N} \\
\mathbf{0}\end{array}$} & \multirow{3}{*}{ Variabel } & \multicolumn{4}{|c|}{ Infertilitas } & \multirow{2}{*}{\multicolumn{2}{|c|}{ Total }} & \multirow{3}{*}{ p value } \\
\hline & & \multicolumn{2}{|c|}{ Kasus } & \multicolumn{2}{|c|}{ Kontrol } & & & \\
\hline & & $\mathrm{F}$ & $\%$ & $\mathrm{~F}$ & $\%$ & $\mathrm{~F}$ & $\%$ & \\
\hline \multirow[t]{4}{*}{1.} & Tingkat stres & & & & & & & \\
\hline & Normal & 35 & 83,3 & 35 & 83,3 & 70 & 83,3 & \multirow{3}{*}{0,906} \\
\hline & Stres ringan & 4 & 9,5 & 2 & 4,8 & 6 & 7,1 & \\
\hline & Stres berat & 3 & 7,1 & 5 & 11,9 & 8 & 9,5 & \\
\hline
\end{tabular}

Tabel 3 memperlihatkan bahwa sebagian besar responden baik dari kelompok kasus dan kontrol berada pada kategori normal dengan presentasi yang sama yaitu sebanyak $83,3 \%$. Hasil uji Spearman menunjukkan nilai $p$ value $>0,05$ ( $p$ value $=0,906)$ yang artinya bahwa tidak ada hubungan yang signifikan antara tingkat stres dengan kejadian infertilitas.

Hasil penelitian ini sama dengan penelitian Oktarina et al yang menunjukkan bahwa wanita mayoritas wanita yang mengalami infertilitas berada pada rentang usia 25 - 35 tahun. Handini dan Mirfat (2017) dalam penelitiannya 
juga menemukan bahwa tidak terdapat perbedaan yang signifikan antara usia pasangan infertile dan tidak infertile. Hasil penelitian ini berbeda dengan penelitian yang dilakukan oleh Indarwati et al (2017) yang menyimpulkan bahwa usia merupakan salah satu faktor yang meningkatkan resiko terjadinya infertilitas dimana wanita yang berusia 35 tahun ke atas beresiko 8 kali lebih besar mengalami infertilitas dibandingkan dengan wanita yang berusia dibawah 35 tahun.

Usia merupakan salah satu faktor penting yang mempengaruhi fertilitas. Semakin tua usia ibu maka kemungkinan untuk hamil akan semakil kecil. Hal ini berkaitan dengan jumlah cadangan sel telur yang ada di ovarium. Pada fase reproduksi wanita akan memiliki cadangan 400 sel telur di dalam ovariumnya. Setiap bulan satu sel telur yang paling dominan akan berkembang dan matang serta siap untuk dibuahi dan mengalami menstruasi bila sel telur tersebut tidak dibuahi. Pada usia 35 tahun simpanan sel telur menipis dan mulai terjadi perubahan keseimbangan hormon sehingga kesempatan wanita untuk hamil menurun. Kualitas sel telur pun menurun sehingga kemungkinan keguguran pun meningkat. Sampai pada akhirnya kira - kira umur 45 tahun sel telur habis sehingga wanita tidak menstruasi lagi yang disebut dengan menopause. Usia yang semakin tua juga memberikan dampak risiko yang lebih besar terhadap kelainan kromosom (Eniola, Adetola and Abayomi, 2012 : Djuwantono et al, 2008).

Pada penelitian ini tidak ditemukan hubungan yang signifakan antara tingkat stress dengan kejadian infertilitas. Hal ini berkebalikan dengan penelitian Setyono et al (2015) yang menunjukkan bahwa semakin tinggi tingkat stres dan kadar kortisol maka akan semakin rendah jumlah folikel dominannya. Stres merupakan bagian dari yang tidak terpisahkan dari setiap individu baik itu stres fisik, sosial maupun psikologis. Tingkat stres secara signifikan memiliki pengaruh yang besar bagi fertilitas pria maupun wanita. Ketika seseorang mengalami stres maka tubuh akan merespon dengan menghasilkan hormon kortisol dari kelenjar adrenal. Produksi hormon ini diatur oleh hipofisa berupa pengeluaran Adreno Corticotrophine hormone (ACTH). Kortisol mempengaruhi hipofisa sehingga menghambat produksi GnRH sehingga mengakibatkan penurunan produksi FSH. Hal ini dapat menyebabkan jumlah folikel primordial yang berkembang menjadi folikel antral menjadi lebih sedikit. Sementara di ovarium, kortisol secara langsung 
menghambat proses steroidogenesis dan menginduksi terjadinya apoptosis. Penghambatan langsung kortisol terhadap estradiol akan mempengaruhi fungsi sel granulosa dan berdampak pada maturasi folikel dan berkurangnya jumlah oosit yang matur serta dapat mempengaruhi kualitas dari oosit tersebut. Akan tetapi, apakah stres yang menyebabkan infertilitas atau sebaliknya belum dapat dipastikan. (Sharma et al. 2013 ; Setiyono et al, 2015).

Perbedaan yang ditemukan pada penelitian ini dapat disebabkan oleh berbagai faktor lain yang tidak diteliti dalam penelitian ini. adanya penyakit penyerta yang diderita oleh responden dapat menjadi salah satu penyebab responden kesulitan memiliki keturunan. Pada variabel tingkat stres, pengambilan data yang dilakukan setelah pasangan didiagnosa mengalami infertilitas sehingga apakah stres yang dialami oleh pasangan merupakan penyebab atau efek dari infertilitas tidak dapat diketahui pasti. Pasangan telah mendapat konseling dari petugas kesehatan mengenai penyebab infertilitas, tindakan yang diperlukan dan peluang pasangan untuk dapat memiliki anak membuat pasangan dapat memahami kondisinya saat ini yang berakibat menurunkan tingkat kecemasan dan kehawatirannya. Penelitian ini menggunakan metode case control dengan pendekatan retrospektif dimana variabel penyebab diidentifikasi setelah variabel akibat ditentukan sangat rentan terjadi bias dan juga terdapat beberapa variabel lain yang tidak diteliti dalam penelitian ini sehingga dapat mempengaruhi hasil dari penelitian ini.

\section{SIMPULAN DAN SARAN}

Hasil dari penelitian ini dapat disimpulkan bahwa tidak terdapat hubungan yang bermakna antara usia ibu dan tingkat stres dengan kejadian infertilitas. Mayoritas responden yang mengalami infertilitas memiliki rentang usia di bawah 35 tahun dan tingkat stres normal.

Hasil dari penelitian ini tidak dapat diterapkan ke populasi yang lebih besar. Walaupun secara statistik usia dan tingkat stres tidak menunjukkan hubungan yang bermakna tetapi secara teori kedua variabel tersebut merupakan salah satu dari faktor yang dapat meningkatkan kemungkinan seorang wanita mengalami infertilitas. Penelitian selanjutnya disarankan untuk dapat meneliti faktor lain yang 
mungkin berhubungan denga kejadian infertilitas yang tidak diteliti dalam penelitian ini.

\section{DAFTAR PUSTAKA}

Andrew, G. (2010) Buku ajar kesehatan reproduksi wanita. Ed 2. Jakarta : EGC Dalono. (2011) Psikosomatik dan sesksologi. Ilmu Kandungan. Edisi Ketiga. Jakarta : Bina Pustaka Sarwono Prawirohardjo. Hal. 467 - 468, 476.

Djuwantoro, T. Permadi, W. (2008) Hanya 7 hari memahami infertilitas. Bandung :PT. Refika aditama

Eniola, W., Adetola, A. and Abayomi, T. (2012) 'A review of female infertility; important etiological factors and management', Journal of Microbiology and Biotechnology Research Scholars Research Library J. Microbiol. Biotech. Res, 2(3), pp. 379-385. Available at: http://scholarsresearchlibrary.com/archive.html.

Fauziyah, Y. (2012) Infertilitas dan gangguan alat reproduksi wanita. Yogyakarta: Nuha Medika.

Hendarto, H. (2011) Stres infertilitas menghambat maturasi oosit dan hasil fertilisasi in vitro. Divisi Fertilisasi Dan Endokrinologi Reproduksi Departement SMF Obstetri Dan Ginekologi Fakultas Kedokteran Universitas Airlangga/ RSUD Dr. Soetomo Surabaya

Hestiantoro, A. (2011) Infertilitas. Ilmu Kandungan. Edisi Ketiga. Jakarta : Bina Pustaka Sarwono Prawirohardjo. Hal. 424 - 435

Hestiantoro, A et al (Ed). (2013) Pedoman konsensus penanganan infertilitas. Jakarta

Indarwati, I. et al. (2017) 'Analysis of factors influencing female infertility', Journal of Maternal and Child Health, 2, pp. 151-162. doi: doi.org/10.26911/thejmch.2017.02.02.06.

Oktarina, A. et al. (2014) 'Faktor-faktor yang memengaruhi infertilitas pada wanita di klinik fertilitas endokrinologi reproduksi', (4), pp. 295-300.

Sa'adah, N. Purnomo, W. (2015) 'Karakteristik dan perilaku berisiko pasangan infertil di Klinik Fertilitas dan Bayi Tabung Tiara Cita Rumah Sakit Putri Surabaya', pp. 61-69.

Sharma, R. et al. (2013) 'Lifestyle factors and reproductive health : taking control of your fertility', Reproductive Biology and Endocrinology. 11(1), p. 1. doi: 10.1186/1477-7827-11-66.

Sari, L. (2016) Cara sehat cepat hamil. Yogyakarta : FlashBooks. Hal 288 - 292

Setiyono, A. Hendarto, H. Prasetyo, B. Maramis, M. M. (2015) Pengaruh tingkat stres dan kadar kortisol dengan jumlah folikel dominan pada penderita infertilitas yang menjalani fertilisasi in vitro. Majalah Obstetri \& Ginekologi, Vol. 23 No. 3 September - Desember 2015. pp 128 - 132.

Vander Borght, M. and Wyns, C. (2018) 'Fertility and infertility: Definition and epidemiology', Clinical Biochemistry, (March). doi: 10.1016/j.clinbiochem.2018.03.012. 